\title{
Quantifying and linking Sustainable Land-water- energy-food nexus: A perspective of sustainable livelihoods in Gidabo Watershed, East African Rift Valley
}

zinabu wolde hatiya ( $\nabla$ sos.zine04@gmail.com )

Nanjing Agricultural University, China https://orcid.org/0000-0002-1611-3611

Wu Wei

Nanjing Agricultural University - Weigang Campus: Nanjing Agricultural University

Haile Ketema

Nanjing Agricultural University

Benjamin Karikari

Gahana Developmental Study University

Original article

Keywords: Local Community, Livelihoods, Sustainability, Land-Water-Energy-Food, Nexus, Indicator

Posted Date: August 19th, 2021

DOl: https://doi.org/10.21203/rs.3.rs-800898/v1

License: (1) (1) This work is licensed under a Creative Commons Attribution 4.0 International License.

Read Full License 
1 Quantifying and linking Sustainable Land-water-energy-food nexus: A

2 perspective of sustainable livelihoods in Gidabo Watershed, East African Rift

3 Valley

${ }^{1}$ College of Land Management, Nanjing Agricultural University, Nanjing 210095, China

${ }^{2}$ National and Local Joint Engineering Research Center for Rural Land Resources Use and Consolidation, Nanjing 210095, China.

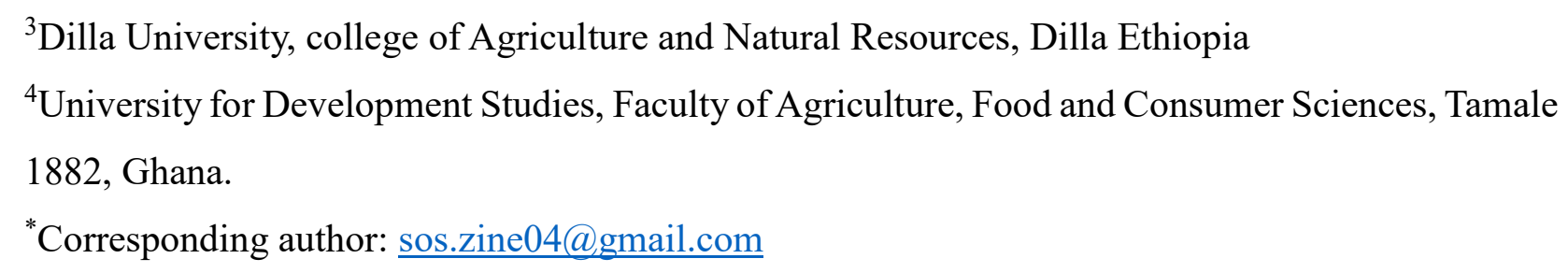

\begin{abstract}
Background

The sustainable management of Land - Water - Energy - Food (LWEF) nexus requires an environmental characterization that allows the comparison of complex interlinkages between nexus resources and livelihoods. This complexity makes this characterization difficult coupled with limited study in quantifying sustainability of LWEF nexus and its linkage with livelihood. Therefore, the present study aimed to investigate the link between sustainable LWEF nexus and livelihoods. We used analytical hierarchy process and pairwise comparison matrix in combination with weighting model.

Result

The result of composite LWEF nexus index was 0.083 representing, low sustainability. This could be linked with nexus resources consumption, use, and management. From the analysis of the weight of land, water, energy and food nexus resources, the highest weight was observed for food. The focus of on food production only shows no clear synergy on provisioning, supporting or regulating nexus resources to address livelihoods. The result further showed that $L W E F$ nexus resources have strong correlation with livelihoods. This was evidenced by social $(r \geq 0.8, P<0.01)$, natural $(r \geq 0.3$, $P<0.05)$ and physical $(r \geq 0.6, P<0.01)$ livelihood indicators showed strong positive correlation with $L W E F$ nexus resources.

Conclusion

Based on the finding of the study, it was observed that managing nexus resources not only provide a significant contribution to achieve sustainable LWEF nexus, but also be effective for enhancing livelihood through food security. This could be attained by strong evidence based policy to ensure sustainable use of nexus resources. The results provided by this study would serve as the foundation for future study, policy formulation and implementation.
\end{abstract}

Keywords: Local Community, Livelihoods, Sustainability, Land-Water-Energy-Food, Nexus, Indicator

\title{
1. Introduction
}

Land, water, energy, and food (LWEF) are natural resources vital for sustaining life on earth (Pimentel et al., 2010; Ringler et al., 2013), and also important for people wellbeing and economic 
activities (Leese and Meisch, 2015). Globally more than 1 billion people suffer from water, energy and food insecurity, and also correspondingly from amplifying land degradation (Beck and Walker, 2013; Rasul and Sharma, 2016). This could be due to population growth, urbanization, rising economy and consequent change in consumption patterns, and climate change, which pose pressure on those four resources (Nie et al., 2019; Spera et al., 2016). Thus, the issue of LWEF security is a big obstacle for global sustainable development (Cairns and Krzywoszynska, 2016; Smajgl et al., 2016; Wichelns, 2017) which predicated to achieve in 2030.

Effective natural resource management via nexus approach is required for the sustainable use of LWEF nexus resource (Ringler et al., 2013). These resources are vital natural resources needed to solve critical global issues of hunger, improving health and building a sustainable and desirable economy. Due to interlinkage between them, the exploitation of one often sets the prerequisite of the abundances of another, therefore, a possible systemic approach to minimize trade-offs and maximize synergies were needed (Kurian et al., 2019; Terrapon-Pfaff et al., 2018). The importance of systemic approaches in the management and governance of natural resources and food systems has been recognized, due to increasing demands for services and growing desires for higher living standards.

The progress towards water, energy, and food (WEF) nexus have motivated many discussions on how to manage these interlinked resources (Kurian, 2017) and broadened to also include other resources or disciplines, such as soil, land use, climate, waste, ecosystems, health, and others, forming an even more multi-dimensional and multidisciplinary concept (Laspidou et al., 2019). Despite the progress in recent years, there remain many challenges in scientific research in adding land as part of the WEF nexus system in small geographical scale (Granit et al., 2012). The scientific challenges are primarily related to data, information and knowledge gaps on the these four nexus resources interlinkage (Liu et al., 2017; Mohtar and Daher, 2016).

This concern suggest the need for a possible assessment system which is based on the concept of 
sustainable natural resource indicator (Leck et al., 2015). A sustainability indicator can be defined as a measurable aspect of environmental, economic, or social systems that is useful for monitoring changes in system characteristics relevant to the continuation of human and environmental wellbeing (Moldan et al., 2012; Rydin et al., 2003; Wolde et al., 2020). Sustainability indicators tend to be the most suitable for providing valuable initial assessment, which necessitates for decisionmaking from grass root level (Chartres and Noble, 2015; Karlberg et al., 2015).

The relationship between nexus resource and livelihoods is said to be a symbiotic relationship in a form of a vicious cycle, due to ability to affect one another (Gashu and Muchie, 2018). So far, ample empirical studies conducted on the link between individual nexus resources and livelihoods, however, studies linking LWEF nexus and livelihood are barely conducted at the study area to analyze the interlink between sustainable LWEF nexus and livelihoods. Therefore, this study specifically seeks to (i) identify LWEF nexus and livelihoods indicators; (ii) analyze sustainability of LWEF nexus and its contribution for livelihoods improvement; (iii) assess the livelihoods strategies and its sensitivity with sustainable LWEF nexus. The findings from this study will add up to the literature on the subject area and provides foundation for future studies, policy formulation and implementation in the study area and beyond.

\section{Materials and Methods}

\subsection{Description of Research Sites}

The study was conducted in the Rift Valley Basin in Ethiopia. The Rift Valley Basin, which passes the southern part of the Main Ethiopian Rift, covers an area of about $0.04 \%$ of the country and extends to the south from the upper catchments of the Awash Basin to the Kenyan border, to the extreme south of Chew Bahir. This Basin lies both in the Oromia and Southern Nation, Nationality and People Regional States. As outlined in the Integrated Development Master Plan Study (2010), the basin is characterized by under development, widespread poverty and severe land degradation. 
92 The Gidabo Watershed is part of Rift Valley Basin, and also called Ethiopian Rift runs through

93 Ethiopia in the southwest direction from the Afar Triple Junction (Elias et al., 2019). This area is

94 characterized by wide topography and climatic variation ranging from humid in the highland to

95 semi-arid (Hassen et al., 2021). It is situated between $6^{0} 9^{\prime} 4^{\prime \prime}$ ' to $6^{0} 56^{\prime} 4^{\prime \prime}$ 'N latitude and $37^{0} 55^{\prime}$ to

$9638^{0} 35^{\prime \prime}$ E longitude, covering an area that is approximately $3549 \mathrm{~km}^{2}$ (Figure 1). The maximum

97 and minimum altitudes are about 3213 m.a.s. 1 and 1171 m.a.s.l respectively.

98 The unique characteristics of the watershed are associated mainly with the results of faulting and volcanism associated with rifting process (Yared, 2019). As a result, the typical rift morphology is well developed which clearly show the upper and lower parts which drain to the common outlet (Figure 1).

The population in the watershed has nearly doubled over the last two decades from 593,157 to over 1.5M (Elias et al., 2019). Increased population in the basin and the socio-economic developments have put pressure on land that consequently declined water and food potential in the watershed (Meshesha et al., 2012). 


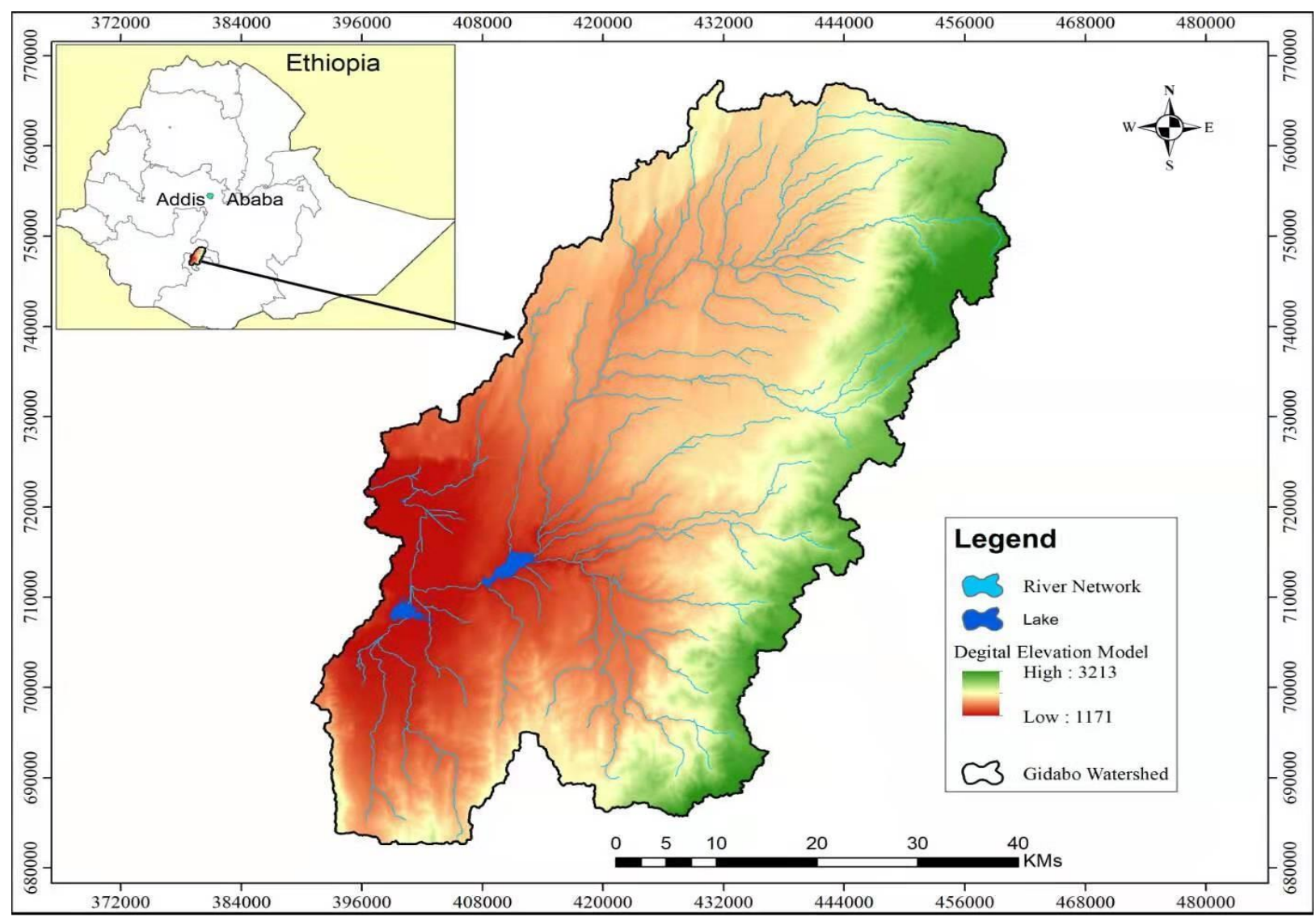

Figure 1:Map of the case study area

Land, water, energy and food nexus resources are all crucial contributors to food security. As a

result of growing resource scarcity, the inter-connectedness of these sectors has become more apparent, as evidenced by growing tradeoffs. Proactive analysis of the current consumption, use and management of LWEF nexus resources are required to holistically assess and promote the best management option that co-balance benefits across LWEF nexus resources as highlighted by WoldeYohannes et al. (2018).

\subsection{Establishment of LWEF nexus indicator and sub-indicators}

Indicators are becoming increasingly important for communicating information to policy makers and stakeholders, as well as for assessing the environmental performance and progress in general (Revell and Henderson, 2019). Nowadays, it is believed that composite indicators have been used for quality of life and environment through providing information on the status of the economic, 
social and environmental component to reduce the number of measurements necessary to give descriptions of an indicator (Estoque et al., 2019; Mazziotta and Pareto, 2019).

It is known that clear indicators are the basis of any effective monitoring, evaluation system and data obtaining system (Rydin et al., 2003). Since, this study is based on local cases one of the challenges in performing this study is obtaining sufficient data and information relevant to our study. In order to track the way in which LWEF nexus and livelihood links and its progress towards reaching certain goals the researcher need to measure this change using literature and key informants having enough knowledge in the area to select and develop indicators.

In order to develop indicators in Table 1, we used the following four stepwise procedures to define the indicator variable; (1) Collecting ideas to perform this we compiled all ideas from key informants without judging them, then we organized the ideas into group to categorize as relating to specific individual objectives and analytical questions. (2) Structure and refine ideas, in this steps we further structured and consolidated the ideas to sort out the relevant ones by referring the work of other researchers/organization or using previously developed sets of indicator. Additionally, this steps helped to remove unnecessary indicator and to merge those having similarity. (3) Formulating indicators to make sure that selected indicator in both meaningful and measurable, we consider specific measurable attainable realistic and timely (SMART) techniques to formulate the indicators that showed what results were likely to be reached within what target group, and in what time frame. (4) Selection of indicator, the assembled indicators through step 1-3 which were many, however, this step focus on indicators quality which is more important than their number, therefore, we set priorities to have a small but meaningful set of indicators.

Following above methods we prioritized the criteria and set indicators for LWEF nexus resources (Table 1). Table 1 indicates the most important LWEF nexus indicators identified from literatures. After designing those indicators, the study used approach of the Analytic Hierarchy Process Table 1: Overview of the LWEF nexus indicators from existing literature 


\begin{tabular}{|c|c|c|c|}
\hline \multirow{4}{*}{$\begin{array}{l}\text { Nexus } \\
\text { component } \\
\text { Land }\end{array}$} & Indicators & Descriptions & Sources \\
\hline & $\begin{array}{l}\text { Land capability } \\
\text { (LI1) }\end{array}$ & $\begin{array}{l}\text { Land capability is the ability of land to support a } \\
\text { given land use without causing damage. Its } \\
\text { assessment considers the specific requirements of } \\
\text { the land use and the risks of degradation } \\
\text { associated with the land use }\end{array}$ & \multirow{3}{*}{$\begin{array}{l}\text { (Akpoti et al., } \\
2019 \text {; Costa et } \\
\text { al., 2019; Donkor } \\
\text { and Owusu, } \\
\text { 2019; Elfimova } \\
\text { et al., 2020; Lee } \\
\text { et al., 2019) }\end{array}$} \\
\hline & $\begin{array}{l}\text { Land suitability } \\
\text { (LI2) }\end{array}$ & $\begin{array}{l}\text { Land capability assessments are a first step in } \\
\text { assessing land suitability for a given use. } \\
\text { Suitability considers other factors such as } \\
\text { economics, infrastructure requirements, labor } \\
\text { access, water and energy access, conflicting and } \\
\text { complementary land uses, and the policy } \\
\text { framework. }\end{array}$ & \\
\hline & $\begin{array}{l}\text { Land productivity } \\
\text { (LI3) }\end{array}$ & $\begin{array}{l}\text { The productivity of land is determined by its } \\
\text { natural qualities and fertility. This indicates all } \\
\text { lands are not equally fertile, which makes some } \\
\text { locations are very fertile and have very good } \\
\text { agricultural productivity, whereas some patches } \\
\text { are non-productive. }\end{array}$ & \\
\hline \multirow[t]{3}{*}{ Water } & $\begin{array}{l}\text { Access } \\
\text { (WI1) }\end{array}$ & $\begin{array}{l}\text { Global water resources are facing increasing } \\
\text { pressure from rapidly growing demands and } \\
\text { climate change, which affect access to water. } \\
\text { Thus, sustainable water management is a key } \\
\text { global concern intricately linked to many } \\
\text { livelihoods worldwide }\end{array}$ & \multirow{3}{*}{$\begin{array}{l}\text { (Harmancioglu et } \\
\text { al., 2020; } \\
\text { Mendoza et al., } \\
\text { 2020; Ray and } \\
\text { Shaw, 2019; } \\
\text { Robinne et al., } \\
\text { 2017; Varis et al., } \\
\text { 2017) }\end{array}$} \\
\hline & $\begin{array}{l}\text { Safety } \\
\text { (WI2) }\end{array}$ & $\begin{array}{l}\text { Unsafe water is one of the world's largest health } \\
\text { and environmental problems, particularly for } \\
\text { poorest in the world. It also exacerbates } \\
\text { malnutrition. }\end{array}$ & \\
\hline & Affordability(WI3) & $\begin{array}{l}\text { The physical availability of water is becoming a } \\
\text { serious challenge, and its absence generate } \\
\text { commensurate impacts on the livelihoods and } \\
\text { human wellbeing. }\end{array}$ & \\
\hline \multirow[t]{2}{*}{ Energy } & $\begin{array}{l}\text { Adequate Supply } \\
\text { to demand (EI1) }\end{array}$ & $\begin{array}{l}\text { About } 40 \% \text { of the global population relies on } \\
\text { traditional use of biomass for cooking and heating } \\
\text { their houses. This both directly and indirectly } \\
\text { linked with environmental disturbances. }\end{array}$ & \multirow{2}{*}{$\begin{array}{l}\text { (deLlano-Paz et } \\
\text { al., } 2019 \text {; } \\
\text { Harmancioglu et } \\
\text { al., 2020; Vivoda, } \\
\text { 2017) }\end{array}$} \\
\hline & $\begin{array}{l}\text { Physical } \\
\text { Availability (EI2) }\end{array}$ & $\begin{array}{l}\text { Today lack of physical availability of energy, } \\
\text { simultaneously affect environmental quality and } \\
\text { growth of socio-economic activity }\end{array}$ & \\
\hline \multirow[t]{4}{*}{ Food } & Availability (FI1) & $\begin{array}{l}\text { Refers to the physical existence of food, whether } \\
\text { from the household's own farm, garden } \\
\text { production, and/or from domestic and } \\
\text { international markets }\end{array}$ & \multirow{4}{*}{$\begin{array}{l}\text { (Chartres and } \\
\text { Noble, 2015; } \\
\text { Elfimova et al., } \\
\text { 2020; Gulati et } \\
\text { al., 2013; Leck et } \\
\text { al., 2015; } \\
\text { Mabhaudhi et al., } \\
\text { 2019) }\end{array}$} \\
\hline & $\begin{array}{l}\text { Access } \\
\text { (FI2) }\end{array}$ & $\begin{array}{l}\text { Refers to the resource's individual has at hand to } \\
\text { obtain appropriate foods for a nutritious diet. }\end{array}$ & \\
\hline & $\begin{array}{l}\text { Utilization } \\
\text { (FI3) }\end{array}$ & $\begin{array}{l}\text { Refers to the actual food that is consumed by } \\
\text { individuals; how it is stored, prepared, and } \\
\text { consumed. And also, what nutritional benefits the } \\
\text { individual drives from consumption. }\end{array}$ & \\
\hline & $\begin{array}{l}\text { Stability } \\
\text { (FI4) }\end{array}$ & $\begin{array}{l}\text { Refers to the temporal dimension, or time-frame } \\
\text { of food security. }\end{array}$ & \\
\hline
\end{tabular}


(AHP), and the pairwise comparison matrix (PCM) to provide weight for individual indicator and

to normalize the indicators and establish composite indicators index.

The AHP is a structured technique, which is helpful in solving indicators selection problems involving multi-criteria and multi-alternatives (de FSM Russo and Camanho, 2015). Furthermore, the hierarchical structure used in formulating the AHP model can enable all members of the evaluation team to visualize the problems systematically in terms of relevant criteria (Mazziotta and Pareto, 2019). In a sense, the AHP method may be useful for selecting indicators because of the characteristics of indicator selection process.

The PCM is a technique which has been widely used to tackle the subjective and objective judgements about qualitative or quantitative criteria in multi-criteria decision making, especially in the AHP (Meixner et al., 2016). The preference relations in the PCMs are filled in by the decision maker's judgments, and presented using different measurement scales such as ratio scale. The importance of criteria and the ranking of alternatives are often judged through the priority weights derived from a PCM, thus many prioritization approaches have been proposed to derive the priority weights from PCM.

The AHP supports creation of weights based on expert's judgments structured in a pair wise comparison matrix by applying Saaty's scale of intensities importance (Saaty, 2016). The tool for data collection for AHP was presented in Microsoft excel, and respondents were asked to rank the 12 comparison matrices. Then, through further calculation, weightings for criteria and indicators within each criterion was computed (Table 2). Mabhaudhi et al. (2019) explained that the full description of how the AHP and PCM normalization works.

Table 2: PCM and weight for the LWEF nexus indicators

\begin{tabular}{|c|c|c|c|c|c|c|c|c|c|c|c|c|c|}
\hline Indicators & LI1 & LI2 & LI3 & WI1 & WI2 & WI3 & EI1 & EI2 & FI1 & FI2 & FI3 & FI4 & Weight \\
\hline LI1 & 1 & & & & & & & & & & & & 0.042 \\
\hline LI2 & 3 & 1 & & & & & & & & & & & 0.050 \\
\hline LI3 & 3 & 0 & & & & & & & & & & & 0.066 \\
\hline
\end{tabular}




\begin{tabular}{|c|c|c|c|c|c|c|c|c|c|c|c|c|c|}
\hline WI1 & 2 & 2 & 2 & 1 & & & & & & & & & 0.069 \\
\hline WI2 & 1 & 1 & $1 / 2$ & $1 / 2$ & 1 & & & & & & & & 0.041 \\
\hline WI3 & 4 & 4 & 3 & 3 & 6 & 1 & & & & & & & 0.149 \\
\hline EI1 & 2 & 2 & 1 & 1 & 4 & $1 / 2$ & 1 & & & & & & 0.069 \\
\hline EI2 & 2 & 1 & 2 & 1 & 4 & $1 / 3$ & 2 & 1 & & & & & 0.075 \\
\hline FI1 & 1 & 1 & 1 & $1 / 2$ & 3 & $1 / 3$ & 1 & 1 & 1 & & & & 0.058 \\
\hline FI2 & 2 & 2 & 1 & 1 & 3 & 1 & 1 & 2 & 2 & 1 & & & 0.096 \\
\hline FI3 & 2 & 1 & 3 & 3 & 2 & 2 & 2 & 3 & 3 & $1 / 3$ & 1 & & 0.150 \\
\hline FI4 & 1 & 3 & 1 & 2 & 1 & $1 / 2$ & 3 & 1 & 2 & 1 & 5 & 1 & 0.135 \\
\hline
\end{tabular}

The computation of each weight, indices, consistence ratio (CR) and consistence index (CI) were computed as follows; before calculating CR, we computed CI using the formula;

$C I=\omega-\frac{n}{n-1}$, where $\mathrm{n}$ represents the number of indicators in our case 12 and $\omega$ represent the eigenvalue obtained from the weight value of indicator using stata 14 , for our case $\omega=1.176$. Therefore,

$C I=\omega-\frac{n}{n-1}, 1.176-\frac{12}{12-1}=1.176-1.09=0.086$

According to Meixner et al. (2016), Random Index (RI) calculated for criteria from $n=1$ 15, provided their RI value hence our criteria (indicator) as 12 , therefore, it corresponding $\mathrm{RI}=1.54$.

$$
C R=\frac{C I}{R I}=\frac{0.086}{1.54}=0.0556, \text { equal to } 0.056
$$

Compared with study conducted by Mabhaudhi et al. (2019), we considered land as additional nexus resources which can be explained by land suitability, capability and productivity were considered as identified indicators. The identified indicators were normalized by applying the indicator weight normalization, and used to compute the LWEF index by adding the weighted normalized indicators.

\subsection{Sustainable livelihoods indicators}

It is crucial to consider nexus resources security for various livelihood indicators through computing indices to evaluate their role in Sustainable Livelihoods (SL). Sustainable livelihoods Framework (SLF) has been considered and it has been found that the good indicators that provide a complete 
picture of all the relevant aspects of sustainable livelihoods in a transparent and easily understandable way (Kumar et al., 2019; Salim, 2019).

Sustainability is an important qualifier to Department for International Development (DFID) view of livelihoods because it implies that progress in poverty reduction is lasting, rather than fleeting (Helmy, 2020). For detail on sustainable livelihoods approach, the five main livelihoods component adopted and explained from (Marker et al., 2002).

Therefore, the current study adopted the DFID SLF to characterize the livelihoods indicators (Nguyen, 2019). The five basic components of livelihood show the variation in people's access to assets. A single physical livelihood component can generate multiple benefits. For example, if someone has secured access to land (natural capital), they may also be well-endowed with financial capital, as they are able to use the land not only for direct productive activities but also as collateral for loans. This helps to develop different sub-livelihoods indicator. Table 3 depicts the basic component of sustainable livelihoods indicators for the current study which were categorized under five main and 23 sub livelihood categories.

The importance of evaluating livelihoods from basic human aspects (i.e., land, water, energy and food) enhances local community understanding towards the management and use of limited nexus resources and to better link with their livelihoods.

Table 3: Component of sustainable livelihood indicators

\begin{tabular}{llll}
\hline Livelihoods & Indicators & Descriptions & Sources \\
component & & & \\
\cline { 2 - 4 } Social & Social interaction (SC1) & Those indicators refer to, (Helmy, 2020; \\
& Knowledge sharing(SC2) & household's connections in Hinshelwood, \\
& Community wellbeing(SC3) & social network, and the trust, 2003; Leese \\
& Income generation(SC4) & reciprocity, and Resources and Meisch, \\
& Perceived benefits(SC5) & sharing qualities of those & 2015; \\
& Community acceptances(SC6) & connections. &
\end{tabular}




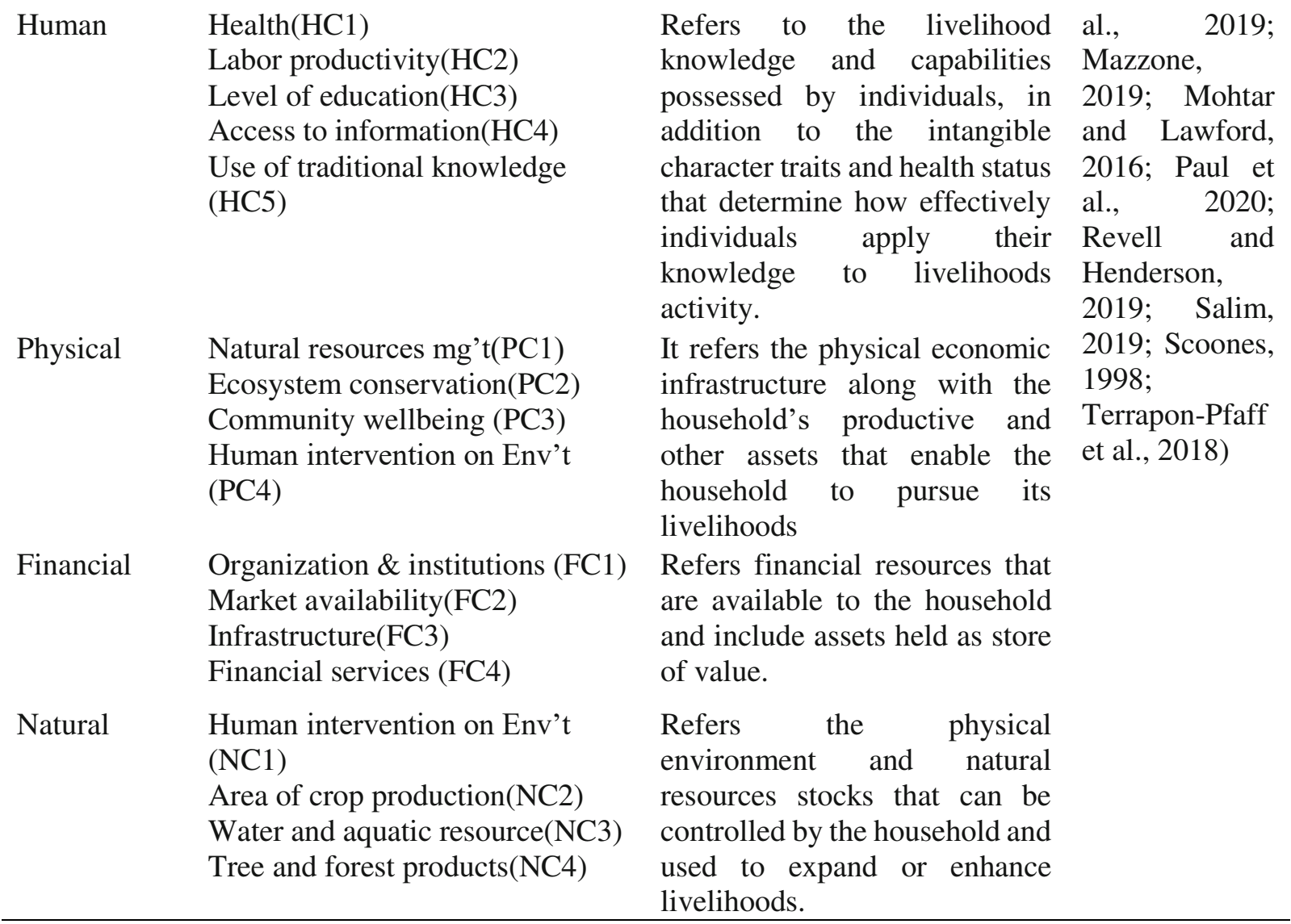

Most researchers have proposed various methods and evaluation of index system to assess the sustainability of WEF nexus in global, national and regional basis (Boas et al., 2016; Chen et al., 2019; Wicaksono et al., 2017; Wicaksono and Kang, 2019). Combining the livelihood indicators helps to measure the interaction between five main livelihoods indicators (Nguyen, 2019). We used the following equation to standardize the sub indicators;

$211 \quad K_{i}=\frac{x i-\bar{x}}{s}$

where $K_{i}$ is sub-indicator, $x_{i}$ corresponds to the $i^{\text {th }}$ measurement of SL indicator variable, $\bar{x}$ is the average value of $x_{i}$ and $s$ is the standard deviation. As a result, we write livelihood component $(L c)$.

where $L c$ the estimated value of the livelihood indicators $(0 \leq i \leq 4)$ in relation to LWEF nexus, $217 w_{i}$ indicates the weight for the $i^{\text {th }}$ observation and $K_{i}$ represents the normalized value of indicator 
for the $\mathrm{i}^{\text {th }}$ observation.

In this paper, we used weighting model (WM) concept to combine the weight of LWEF nexus and livelihoods indicators indices selected from literature as explained in Table 1 and 2. This model helps to determine an index system that could evaluate LWEF system to associate with sustainable livelihoods using weights of individual indicator which helps to develop composite indicator value and the resulting ranking (Yang et al., 2018). There are studies conducted on exploring WEF nexus sustainability (Mabhaudhi et al., 2019; Shahzad et al., 2017; Yang et al., 2018). However, our study tries to link sustainability of nexus resources and livelihoods which have not been studied so far from small geographical units in Ethiopia, particularly in Gidabo watershed. This provides some degree of novelty to the current work.

\subsection{Sample size determination and Sampling Technique}

The data on LWEF nexus resources and livelihood indicators for the study were sourced from both secondary and primary sources. The primary sources involved the combination of structured interviews with local community and key informants. The survey was conducted within four-month period from July 2019 to October 2019 following two approaches. First, we made expert interview $(\mathrm{N}=50)$ and focus group discussion with experienced expert from natural resources, agriculture, water and energy sector to characterize the sub-indicators for LWEF and livelihood Table 1 and 2. Particularly, the identification of indicators helps for household to easily categorize which livelihood indicators linked with LWEF nexus resources. Second, a structured questionnaire was administered to 434 farmer household heads $(\mathrm{N}=434)$. The structured questionnaire mainly focused on assessing the importance of the proposed LWEF nexus indicators for sustainable livelihood indicators (SLI) using Likert scale (0-4, where 0=Not Important; 1=Slightly Important, 2=Moderately Important, 3=Important, 4=Very Important) was adopted for this study.

Based on the weight of indicators, we further used logistic regression to describe the causal relationship between LWEF nexus indicators (i.e. independent variable $N$ ) and livelihoods 
indicators (i.e. dependent variable $\delta$ ). When using the logistic regression, we need to make an algebraic explanation to arrive at our usual linear regression equation. The logistic regression is given by:

$$
\delta=\beta_{0}+\sum_{i=0}^{n} \beta_{i} N_{i}
$$

where $\delta$ is probability, $\beta_{O}$ is the constants, and $\beta_{i}(i=1,2, \ldots, n)$ is the regression coefficients. In our case the dependent variables $(\delta)$ is not continuous, and converted to probability ratio $(\omega)$ of livelihoods indicators and computed as;

$$
\ln (\omega)=\ln \left(\frac{\delta}{1-\delta}\right)
$$

where $\ln =$ natural logarithm, and $\omega$ is called logit $(\delta)$, leads to the following equations;

$$
\operatorname{Logit}(\delta)=\beta_{o}+\sum_{i=1}^{n} \beta_{i} N_{i}
$$

where $\beta_{O}+\sum_{i=1}^{n} \beta_{i} N_{i}$ is familiar equation for regression line. Knowing regression equation helps to calculate expected probability from a given values of $N_{i}$ theoretically. From this equation (5) is changed to:

$\omega=\frac{\delta}{1-\delta}=\exp \left(\beta_{o}+\sum_{i=1}^{n} \beta_{i} N_{i}\right)$

To rearrange the equation, the opposite of natural logarithm(exp) is considered since we need to estimate the probability of livelihoods indicators. This can be explained with the change in units' value of $N_{i}$. Finally, elasticity of probability was determined from the derivatives equation of (6) as from equation 7 below;

$$
\omega=\exp \left(\beta_{j}+\beta_{o}+\sum_{i=1}^{n} \beta_{i} N_{i}\right)=\omega \exp \left(\beta_{j}\right)
$$

where $\exp \left(\beta_{j}\right)$ is the elasticity probability, it changes with the unit increases and decreases in nexus resources $\left(N_{i}\right)$. It shows how main livelihoods indicators are sensitive with respect to land, water, energy and food nexus indicators. In this analysis sensitivity measure the effect of changing in nexus resources in the livelihoods indicators. This means that the probability of LWEF nexus resources increase by $\exp \left(\beta_{j}\right)$ increase or decrease the livelihoods by one unit change based on the 
regression coefficient. From the regression coefficient computed student t-test was applied to test which nexus resources comparably influential using mathematical equation;

$$
N_{O}=\frac{\beta_{i}}{\sqrt{\delta^{2}+C_{n n}}}
$$

Where $N_{o}$ is nexus resources with $k-m-l$ degree of freedom, with $k$ being the total number of samples and $\mathrm{m}$ the number of terms in the model, $\beta_{i}$ is the regression coefficients, the term $C_{n n}$ is the $\mathrm{n}^{\text {th }}$ diagonal elements of the data matrix, and $\delta^{2}=\sqrt{\frac{S S E}{m-k}}$. All statistical analysis was done in Stata 14 (StataCorp LP, 4905 Lakeway Drive, College Station, TX 77845, USA).

\section{Result and Discussion}

\subsection{Pairwise comparison matrix for land-water-energy and food nexus indicators}

Human well-being, poverty reduction and sustainable development are largely dependent on land, water, energy and food resources. These vital resources are projected to have demand exceeding supply in the nearest future due to population growth and migration, economic development, international trade, urbanization, diversifying diets, cultural and technological changes, as well as climate variability and change ( $\mathrm{Li}$ et al., 2019). These necessitate sustainability of basic nexus resources, which can be assessed by performing the LWEF nexus indicator using PCM.

Table 4: Normalized pairwise comparison, Consistence ratio and composite index for LWEF nexus resources in the study area

\begin{tabular}{llllllllllllll}
\hline Indicators & LI1 & LI2 & LI3 & WI1 & WI2 & WI3 & EI1 & EI2 & FI1 & FI2 & FI3 & FI4 & Indices \\
\cline { 2 - 6 } & 0.04 & 0.02 & 0.02 & 0.03 & 0.06 & 0.05 & 0.03 & 0.04 & 0.03 & 0.08 & 0.05 & 0.06 & 0.042 \\
LI2 & 0.13 & 0.05 & 0.03 & 0.03 & 0.06 & 0.04 & 0.03 & 0.04 & 0.03 & 0.08 & 0.05 & 0.04 & 0.050 \\
LI3 & 0.13 & 0.10 & 0.06 & 0.03 & 0.06 & 0.05 & 0.13 & 0.04 & 0.03 & 0.08 & 0.03 & 0.06 & 0.066 \\
WI1 & 0.08 & 0.10 & 0.12 & 0.07 & 0.06 & 0.05 & 0.03 & 0.02 & 0.13 & 0.08 & 0.03 & 0.06 & 0.069 \\
WI2 & 0.04 & 0.05 & 0.03 & 0.03 & 0.03 & 0.02 & 0.02 & 0.02 & 0.02 & 0.05 & 0.05 & 0.13 & 0.041 \\
WI3 & 0.17 & 0.20 & 0.18 & 0.21 & 0.19 & 0.14 & 0.13 & 0.22 & 0.19 & 0.08 & 0.05 & 0.04 & 0.149 \\
EI1 & 0.08 & 0.10 & 0.06 & 0.07 & 0.13 & 0.07 & 0.06 & 0.04 & 0.03 & 0.08 & 0.05 & 0.06 & 0.069 \\
EI2 & 0.08 & 0.05 & 0.12 & 0.07 & 0.13 & 0.05 & 0.13 & 0.07 & 0.03 & 0.08 & 0.03 & 0.06 & 0.075 \\
FI1 & 0.04 & 0.05 & 0.06 & 0.03 & 0.09 & 0.05 & 0.06 & 0.07 & 0.06 & 0.08 & 0.03 & 0.06 & 0.058 \\
FI2 & 0.08 & 0.10 & 0.06 & 0.07 & 0.09 & 0.14 & 0.06 & 0.15 & 0.13 & 0.15 & 0.09 & 0.03 & 0.096 \\
FI3 & 0.08 & 0.05 & 0.18 & 0.21 & 0.06 & 0.28 & 0.13 & 0.22 & 0.19 & 0.05 & 0.09 & 0.25 & 0.150 \\
FI4 & 0.04 & 0.15 & 0.06 & 0.14 & 0.03 & 0.07 & 0.19 & 0.07 & 0.13 & 0.15 & 0.46 & 0.13 & 0.135 \\
\hline
\end{tabular}


Table 4 presents the result of PCM of the four nexus resources indicators. The comparison of indicators with itself is one. The symmetrical characteristics of the matrix is explained by considering the lower half the triangle, since the remaining cells are the reciprocals of the lower triangle. According to Saaty (2016), the relationships are established using a scale ranging from 1 to 9 and their reciprocals. The result shows that the indicators with the highest weights are the food utilization, water affordability, food stability and access to food (Table 2). This indicates how the percentage of food and water nexus component predict the livelihoods dependences compared with others. Table 4 indicates the CR for the LWEF nexus is 0.056 , a value lower than 0.10 which shows the weights calculated are consistent enough to construct an index as reported by Mabhaudhi et al. (2019).

\subsection{Land-Water-Energy- Food (LWEF) nexus composite indices}

AHP is a widely used method for indicator performance evaluation (de FSM Russo and Camanho, 2015; Nhamo et al., 2020), presumably because it elucidates preference information from the decision makers in a manner which they find easy to understand (Banwet and Deshmukh, 2008). The basic step was undertaken by the pairwise comparison to determine the relationship among WEF nexus components in the study area.

It shows AHP helps to formulate and analyze sustainability indicators (Ray and Shaw, 2019). Our study utilizes LWEF nexus indicators outlined in Table 1 and overlay the transparent and clearly defined weighted criteria which used in importance index scenario. The idea behind composite LWEF nexus index is to aggregate indicators about the sustainability aspects and then provides an easy to understand scoring system to determine sustainability.

LWEF nexus composite index for the study region is 0.083 (Table 4), which implies shows low index (Mabhaudhi et al., 2019; Nhamo et al., 2020). For example, study conducted by Mabhaudhi et al. (2019), on the WEF nexus integrated index for South Africa was 0.145 and categorized as 
low index revealing unsustainable performance of resources utilization and management, which is consistent with our finding. It is known that the case study area is more likely dominated by agriculture based livelihoods, but the expansion of non-agriculture based industries demanding for more land, water and energy are managed friendly in environmentally sustainable way to the extent that natural resource levels are improving rather than deteriorating.

The sustainability index is used to simplify the complex decision making process that will help the stakeholders to come with more sustainable solution (Rydin et al., 2003). Identifying of these indices is crucial since, LWEF nexus index computed from indicators are strongly linked with the livelihoods of local community.

The regional performance of natural resources index is not yet designed, which could lead to nexus resources trade-off. However, there has been wide ranging support for individual and sectorial based management of nexus resources. Lack of managing those interlinked resources in joint way creates a tension in sustaining and supplying sufficient basic resources for human well-being.

The result of low composite index for LWEF shows lack of management of nexus resources in integrated approach, while food production merely considered as core element, as also reported by Mabhaudhi et al. (2019). This is also evidenced by the highest normalized weight of food indicators (Table 2), which shows that land has been overlooked to be part of nexus resources component, while it affects overall performance of nexus resources. For example, Ethiopia has the potential for arable land and water sources (Karlberg et al., 2015), however millions of people still suffer from food and water insecurity, and inadequate of modern energy supply.

Ethiopia depends on hydropower as the main sources of energy, in which food production and energy compete for the same water resources. Similarly, agriculture is a source of economy for over $80 \%$ of population, major means of livelihood for over $80 \%$ of population, this indicates strong dependence of livelihoods on land, water and energy for food production with varied level of consumption. However, agriculture is seriously challenged by human-induced factors, which pose 
pressure in the transformation of rural livelihoods, which need sustainable natural resource management. Nevertheless, the current unsustainability of LWEF nexus resources shows that, the sectorial based nexus resource management and practices indeed significantly impacts both resources and the livelihoods.

\subsection{Land-Water-Energy-Food nexus analytical livelihoods framework}

Local communities, especially the rural poor in the developing world, depend directly on all or part of nexus resources for their livelihood (Mohtar and Lawford, 2016). Therefore, understanding and consensus building are necessary to identify, create and utilize nexus approach in order to reduce trade-off. Current study identified twenty-three sustainable livelihoods indicators which are linked with land, water, energy and food nexus resources (Table 3).

Table 5 shows from the social livelihoods indicators the community acceptances ranked as the most important indicators compared with others. This indicates that, the community acceptance of LWEF nexus resources as a source of livelihoods can be considered from multipurpose utilization of nexus resources for multiple sources of their livelihoods.

Table 5: Community based livelihoods indicators weight and rank in relation to LWEF nexus

\begin{tabular}{|c|c|c|c|}
\hline \multirow{7}{*}{$\begin{array}{l}\text { Main } \\
\text { livelihoods } \\
\text { component } \\
\text { Social }\end{array}$} & Sub-Indicators & $\begin{array}{l}\text { Average weight of } \\
\text { indicators }\end{array}$ & Rank \\
\hline & Social interaction & 0.176 & 3 \\
\hline & Knowledge sharing & 0.122 & 4 \\
\hline & Community wellbeing & 0.244 & 2 \\
\hline & Income generation & 0.130 & 5 \\
\hline & Perceived benefits & 0.079 & 6 \\
\hline & Community acceptances & 0.250 & 1 \\
\hline \multirow[t]{5}{*}{ Human } & Health & 0.300 & 1 \\
\hline & Labor productivity & 0.245 & 2 \\
\hline & Level of education & 0.214 & 3 \\
\hline & Access to information & 0.131 & 4 \\
\hline & Use of traditional knowledge & 0.109 & 5 \\
\hline \multirow[t]{4}{*}{ Physical } & Natural resources mg’t & 0.170 & 3 \\
\hline & Ecosystem conservation & 0.223 & 2 \\
\hline & Community wellbeing & 0.452 & 1 \\
\hline & Human intervention on Env't & 0.155 & 4 \\
\hline Financial & Organization \& institutions & 0.255 & 2 \\
\hline
\end{tabular}




\begin{tabular}{lllll} 
& Market availability & 0.230 & 3 & \multirow{2}{*}{350} \\
& Infrastructure & 0.287 & 1 & \\
\cline { 2 - 5 } Natural & Financial services & 0.228 & 4 \\
& Human intervention on Env't & 0.067 & 2 \\
& Area of crop production & 0.307 & 1 \\
& Water and aquatic resource & 0.319 & 3 \\
\hline
\end{tabular}

Unsustainability of LWEF nexus, in this study (0.083), shows vulnerability of local community for social livelihoods insecurity. To address these challenges, shift from individual nexus resources management are the natural stage for the sustainable LWEF nexus in relation to local community. From the human livelihood component, health is ranked as the most important indicators linked with sustainable LWEF (Table 5). The demand for food production steadily increases with population growth and all of this happens in the light of changing livelihoods, while millions of people do not have access to nutritious food that guarantees a healthy and active life. This is strongly linked with lack of productive land, water and energy sources. Ringler et al. (2013) depicted that, rising food prices, and the recurrence of extreme weather events are pushing more people into poverty and hunger, compromising human health and well-being. Likely, other indicators such as labor productivity, level of education, and knowledge sharing through information also depend on distribution and use of nexus resource.

Physical component of livelihoods indicators includes four indicators (Table 5). The community well-being and ecosystem conservation ranked the first and the second, respectively. This implies that community based nexus resources management has been widely taken as a strategy that aims to conserve LWEF, while simultaneously enhancing livelihoods of local community.

Decentralizing management of nexus resources to local communities improves household's access to and management of nexus resources (Granit et al., 2012). Thus, LWEF nexus upkeep as a tool to enhance nexus resources insecurity and resilience for sustainable livelihoods and ecosystem conservation. Therefore, the concept of nexus resources management should be viewed as longsighted and includes humankinds' harmonious and gradual modification of all ecosystem. 
LWEF nexus are complex multifunctional systems, which need a mosaic of four nexus resources to be properly utilized to increase social, physical, human, financial and natural livelihoods.

\subsection{Comparison and validation of LWEF nexus and livelihoods}

To compare and validate how LWEF nexus affects livelihoods, the impact of nexus resources indices was evaluated using regression analysis. Before regression analysis, the association between the composite weight of both LWEF nexus and livelihood indicators are computed by correlation analysis (Table 6).

The correlation coefficients between livelihoods and LWEF nexus indicator indicates that the social livelihoods indicators (SLI) have strong significant positive correlation $(r \geq 0.80, \mathrm{P}<0.01)$ with land indicator (Table 6). This implies land is social resources upon which people draw in pursuit of their livelihood objectives and have significant contribution for sustainable livelihood. In addition, it has significant positive correlation with LWEF nexus indicators $(\mathrm{r} \geq 0.30, \mathrm{P}>0.05)$. This result suggests that the social livelihood indicators are directly depend on land as a sources of WEF nexus (Table 6).

This result is in relation with finding of Laspidou et al. (2019), who reported that livelihoods and natural resources have direct correlation with social livelihoods indicators. The natural livelihoods indicators had positive correlation $(r \geq 0.30, \mathrm{P}<0.05)$ with water and energy indicators (Table 6). This result shows natural capital is very important to those who derive all or part of their livelihoods from resource-based activities (farming, fishing, gathering in forests, irrigation water dependent and others).

Table 6: Correlation matrix for the composite weight of LWEF nexus and Livelihoods indicators 
Likewise, physical livelihoods indicators have strong significant positive correlation with energy $(\mathrm{r} \geq 0.60, \mathrm{P}<0.01)$, pinpointing that infrastructure consists of changes to the physical environment

\begin{tabular}{|c|c|c|c|c|c|c|c|c|c|}
\hline & SLI & LI & FLI & FI & NLI & WI & PLI & HLI & EI \\
\hline SLI & 1 & & & & & & & & \\
\hline LI & $0.8418 * *$ & 1 & & & & & & & \\
\hline FLI & 0.0625 & $0.1457 *$ & 1 & & & & & & \\
\hline FI & $0.3200 *$ & $0.3880^{*}$ & $0.1427 *$ & 1 & & & & & \\
\hline NLI & $0.6522 *$ & $0.6185 * *$ & 0.0514 & $0.3935 *$ & 1 & & & & \\
\hline WI & $0.3346^{*}$ & $0.3454^{*}$ & 0.0363 & $0.4384 * *$ & $0.3961 *$ & 1 & & & \\
\hline PLI & $0.3018 *$ & $0.4399 * *$ & $0.1261 *$ & $0.7026 * *$ & $0.3364 *$ & $0.3802 *$ & 1 & & \\
\hline HLI & $0.0952 *$ & $0.1740 *$ & $0.1915^{*}$ & $0.2971 *$ & 0.0755 & $0.934 * *$ & $0.1801^{*}$ & 1 & \\
\hline EI & $0.3081 *$ & $0.3744 *$ & $0.1362 *$ & $0.9840 *$ & $0.3834 *$ & $0.4403 *$ & $0.6950 * *$ & 0.432 & 1 \\
\hline
\end{tabular}

that help people to meet their basic needs and to be more productive. In general, the relationships

between LWEF nexus and livelihoods indicators play an important role in the overall performance of livelihoods of local community.

The regression coefficients of land $\left(\beta=0.82^{* *}, \mathrm{P}<0.01\right)$ and food $(\beta=0.01 *, \mathrm{P}<0.05)$ indices imply that, land and food have a significant positive effect on the composite social livelihood indicators (Table 7). Comparably, the effect of land is slightly stronger than that of food indicators. This ensures that sustainable land use management enhances food security and also promotes biodiversity conservation, in agreement with the finding of Hurni et al. (2010). However, the current study reveals the low sustainable composite index of LWEF, (0.083) (Table 4) is an indication of unsustainable land use, which leads to the vulnerability of livelihood of the local community.

Table 7: Statistical analysis and testing of livelihoods indicators with respect to LWEF nexus

\begin{tabular}{lllll}
\hline Main $\begin{array}{l}\text { Livelihoods } \\
\text { indicators }\end{array}$ & Land & Water & Energy & Food \\
\cline { 2 - 5 } Social & $0.8175^{* *}$ & 0.5463 & -0.0635 & $0.0114^{*}$ \\
& $(0.2834)$ & $(0.02676)$ & $(0.02549)$ & $(0.2538)$
\end{tabular}




\begin{tabular}{lllll} 
Human & 0.06873 & $-0.0909 *$ & -0.1572 & $0.5534^{*}$ \\
& $(0.03604)$ & $(0.03405)$ & $(0.3243)$ & $(0.3223)$ \\
Physical & $0.1391 * *$ & 0.0317 & 0.1896 & $-0.6042 *$ \\
& $(0.02718)$ & $(0.0325)$ & $(0.2445)$ & $0.2430)$ \\
Financial & $0.0969^{*}$ & -0.0433 & -0.1335 & 0.3073 \\
& $(0.0436)$ & $(0.0411)$ & $(0.3923)$ & $(0.3899)$ \\
Natural & $0.3523 * *$ & $0.1047 * *$ & -0.0579 & 0.2028 \\
& $(0.0277)$ & $(0.0262)$ & $(0.2497)$ & $(0.2482)$ \\
Constants & $6.3296^{*}$ & $12.939 * *$ & -0.9016 & $13.369 * *$ \\
& $(2.7217)$ & $(3.4625)$ & $(2.6109)$ & $(4.1992)$ \\
\hline
\end{tabular}

412 The composite water index significantly affects human livelihoods indicators $(\beta=-0.09, \mathrm{P}<0.05)$. Human capital is required in order to make good uses of limited water resources which helps for the achievement positive livelihood outcome. The negative coefficient value of water index indicates a single unit change in water management have a negative impact on the livelihoods performance. Chen et al. (2018), stated that water is the critical resources which underpins all social and economic activity.

Table 7 shows, land $(\beta=0.14, \mathrm{P}<0.01)$ and food $(\beta=-0.60, \mathrm{P}<0.05)$ nexus indicators have significant effects on the physical livelihoods indicators. This implies that land indicators significantly improve the community well-being and ecosystem conservation (Table 5), while the food indicators reduce physical indicators performance. This shows that the performance of land capability, suitability and productivity and food production has increased or decreased through the method of adjusting the physical livelihoods indicators, such as physical economic infrastructure that enable the household to pursue its livelihoods.

Table 7 shows that food as nexus component indicators $(\beta=0.5534, \mathrm{P}<0.05)$, which significantly affects the health, labor productivity and education, indeed major indicators of human livelihoods with maximum weight and rank. Table 7 shows, land $(\beta=0.1391, \mathrm{P}<0.01)$ and food $(\beta=-0.6042, \mathrm{P}<0.05)$ nexus indicators have significant effects on the physical livelihoods indicators. This implies that land indicators significantly improve the community wellbeing and ecosystem conservation, while the food 
indicators reduce physical indicators performance. This shows that the performance of land capability, suitability and productivity and food production has increased or decreased through the method of adjusting the physical livelihoods indicators, such as physical economic infrastructure that enable the household to pursue its livelihoods.

The coefficients of the land $(\beta=0.35, \mathrm{P}<0.01)$ and water $(\beta=0.10, \mathrm{P}<0.01)$, indicates that both nexus resources have positive influence on the natural livelihoods indicators (Table 7). This implies land and water are key environmental services in which food is produced from as a natural capital. Thus, the livelihoods of local community are strongly linked with the nexus resources components. Therefore, to overcome the current unsustainability of nexus resources, there is a need for paradigm shift from business as usual to nexus resource management approach which needs to start from grass root level.

With the exception of all nexus resources, understanding energy as part of nexus resources is very critical. Since, energy availability and access would have a wide range of positive externalities on various dimension of human welfare. However, the impact of modern energy on sustainable livelihoods is less known. Therefore, due to the potential dependences of local community on traditional energy sources they fail to consider energy as nexus component. This pose unintended pressure on the environment.

This shows the need of sustainable management of LWEF nexus as an important analytical tool for transforming livelihoods. With this, the idea of nexus resources sustainability has received wider attention, however weighting, ranking and linking with the livelihoods will be the most important to predict the range of acceptable nexus resources impacts and community coping strategies.

\subsection{Analysis of overall LWEF nexus Performance in Livelihoods}


Sensitivity analysis of nexus resources in resources scarce areas has helped local communities to achieve their goal of improved livelihoods. The sensitivity analysis computed using additional regression to analyze the influence of each composite nexus resources indicators on livelihoods.

Table 8 indicates the sensitivity analysis for LWEF nexus and five main livelihoods indicators, the sensitivity judgment scale was adopted from Hosmer and Lemeshow (2000). The result show that, the probability of livelihoods, particularly social component increases by $89.1 \%$ if nexus resources, i.e. food increased by $1.00 \%$ (Table 8 ).

This implies increased food production could enhance social livelihoods indicator. In addition, human, financial and physical livelihoods components show the same trends. This indicates that all the livelihoods indicators have the probability to be influenced by food availability, access, utilization and stability. Likely, the probability of natural livelihoods increases by $69.20 \%$ if food increases by one unit. This suggests that the ability of households to undertake the production of food is strongly associated with their access to natural livelihood component i.e. farmland.

The probability of a unit increases in water as one nexus resources increases the social, human and financial component of livelihoods by $79.90,69.60$ and $69.10 \%$ respectively (Table 8). This pinpoints that water is the critical nexus resources which underpins all social and economic activity since clean, healthy and sustainable water supply strongly linked with the livelihoods of local communities.

Table 8: Sensitivity estimation of LWEF nexus to livelihoods components

\begin{tabular}{lcccr}
\hline & \multicolumn{3}{c}{ Nexus resources } \\
\cline { 2 - 5 } Livelihoods & Land & Water & Food & Energy \\
\hline Social component & 0.705 & 0.799 & 0.891 & 0.794 \\
Human component & 0.778 & 0.696 & 0.781 & 0.698 \\
Financial component & 0.673 & 0.691 & 0.776 & 0.683 \\
Physical component & 0.678 & 0.696 & 0.751 & 0.688 \\
Natural component & 0.637 & 0.656 & 0.692 & 0.648 \\
\hline
\end{tabular}

In general, the overall sensitivity analysis indicates that the probability of livelihoods dependences in the four nexus resources is greater than $50 \%$ in the study area. This indicates the current 
unsustainable condition of nexus resources which is 0.083 will have more than $50 \%$ of livelihoods vulnerability and need serious stakeholder intervention in the area.

In order to measure the extent of nexus resources sustainability indicators and its impact on the livelihoods of local community, we performed the spider web analysis. Figure 2 a shows the proximity between land and livelihoods indicator. It depicts that social and financial livelihoods indicators are closer to land nexus component more than either physical, human or natural 


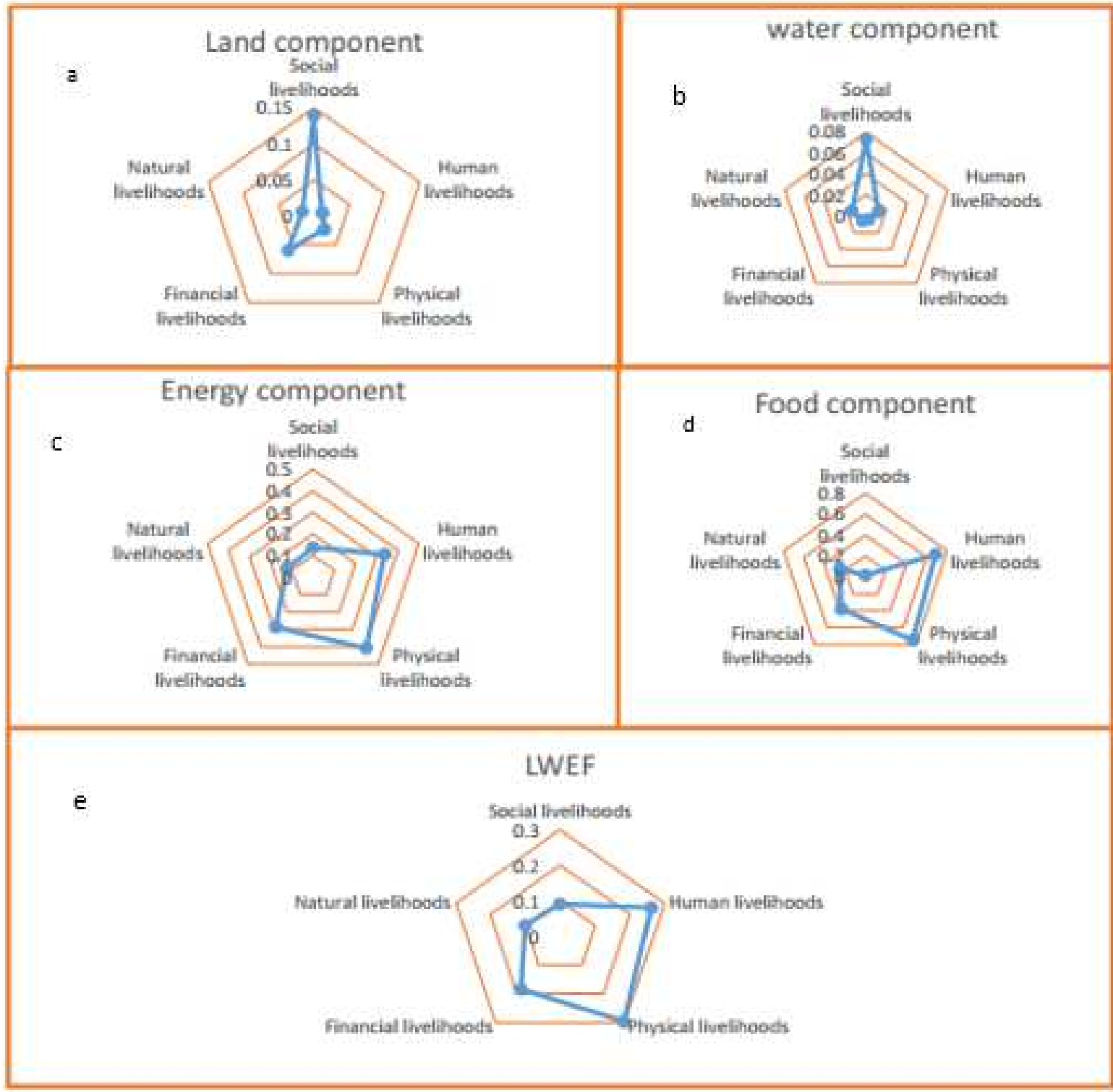

Figure 2: The spider web showing the weight of change of LWEF nexus resources indicators on livelihoods indicators.

reduce costs and increases benefits for both human and nature, however a deeper understanding of

502 the complex dynamics of these system, and their feedback mechanism are yet to be developed by scholars. This made significant contribution to nexus resources degradation which leads to vulnerability of local community.

Under such consequence, the rural poor community bare to the effect of uncoordinated management of nexus resources. This is due to lack of nexus concept emphasis on natural resources, and integrated management of sectors to be demand driven. Therefore, there is a need for paradigm 
shift from rigid and sectorial based nexus resources management for economic development and livelihoods improvement.

\section{Food First Verses Sustainable Livelihood Approach}

Rapid population's growth, land degradation and, climatic variability are factors affecting increasing demand of water, energy and food for smallholder farmers (Khan et al., 2009), and this makes food production slow thereby declining productivity.

Food production without keeping the causal impact of land use, water and energy indeed significantly affects the total amounts of food produced, as well as related ecosystem disturbances. All the nexus resources are linked with the livelihoods of local community with varying extent (Figure 2). This indicates lack of understanding and trade-off among nexus resources and continues to have undesirable impacts on the livelihoods.

Approaches that focuses narrowly on one component of the LWEF nexus without paying attention to its synergies risks major unintended consequences (Gulati et al., 2013). For example, lack of energy in rural area, make local community to depend on forest tress, shrub wood and crop biomass as a sources of fire wood, which is becoming as silent degradation factors (Mekuria et al., 2019). Therefore, singular approach, i.e. food centered approach cannot sustain livelihoods of local community, because cascading failures in one system may occur in other (Mabhaudhi et al., 2019). Since, failures in land use management lead to increase risk of failures in food productions and hydrological variability. This study discovered that the livelihoods of local community in the study area has been decreasing due to over dependence on fragmented land and rain-fed agriculture. This demonstrates that agricultural productivity without proper land use management and use of water and energy sources as inputs potentially affect food production.

Apparently, there is no effective identification of LWEF nexus resources sustainability to inform local community on resources variability events so that they can plan for coping and adapting to events. As shown in Table 4, the composite nexus resources index 0.083 , conveyed to have adequate 
impacts on social, human, physical, financial and natural livelihoods indicators. The result shows the need for site specific planning, coordination and monitoring of nexus resources, is vitally important particularly for developing country like Ethiopia. Because, in the last four decades, the country has undergone dynamic land use change, which remarkably affecting water, energy and food systems. Individual focus on food production, may have impact in individual area of land, water and energy. However, the close relationships, interaction, and interdependences among these resources are usually not taken into consideration. Yet solving one challenge in managing one resources often creates challenge for other resources, therefore the better solution is managing nexus resources collectively using nexus approach.

\section{Policy Implication}

Understanding LWEF nexus sustainability necessitates a readily accessible institutional structure and make-up to build integrated policy. Issues on how to promote potential synergies and trade-off exists among nexus resources pose great challenge to natural resource management. Studies on LWEF nexus have found some useful measure to deal with nexus resources trade-off (Kurian, 2017; Nie et al., 2019). As an example, land use change in expense of food production results in conflict between irrigation water and hydropower (Rasul and Sharma, 2016). These seek policy that sustainably intensify food production and poverty reduction measure, which has profound implication for unique environmental management.

Policy is the main driving force for sustainable natural resources. In fact, food security and growing demand of nexus resources result in unsustainable use and management of nexus resources, which needs critical policy intervention. In order to address such issues, a range of policy measure could be investigated to safeguard and enhance LWEF nexus. These could involve regulation of land use change, reduction of inefficient use of water, expansion of alternative energy sources, reduction of biomass energy sources and use of technology-based approach. These efficiently resonate with sustainable livelihoods. Indeed, application of integrated management of nexus resources in line 
with livelihoods ensure environmental security. This above findings highlight implication for the sustainability of LWEF nexus resources in the context of food security.

Lastly but not the least, sustainability of LWEF nexus resources needs synergies in policy formulation when considerably food security links with livelihoods strategy. Local communities are often vulnerable to social, human, physical, financial and natural component of livelihoods to develop sustainable livelihoods strategy, the nexus approach has become useful tool for selecting and adopting site specific policy measure to enhance human-environment relation. These provide a strong evidence base for decision makers to ensure sustainable use of land, water, energy and food security for livelihoods.

\section{Conclusions}

Sustainability of LWEF nexus resources becoming a critical resource in global, national, regional and local scale, in particular. To address these challenges, in this paper we present quantification and linkage analysis for sustainable LWEF nexus resources and livelihoods. Using a case study design, we generated qualitative data through focus groups and interviews with households and key informants representing a broad cross-section of actors, including participant from land use, agriculture, water and energy sector.

It was found that LWEF nexus composite index for the study region is 0.083 indicating low index. This implies there is unsustainable consumption, use and management of nexus resources in the study area in which exploitation levels came to exceed resources' natural regeneration. Such overexploitation ultimately threatens the livelihoods and wellbeing of people who depend on these resources, and jeopardizes the health of overall environment.

Also LWEF nexus resources had positive correlation with livelihoods, thus social $(\mathrm{r} \geq 0.8, \mathrm{P}<0.01)$, natural $(\mathrm{r} \geq 0.3, \mathrm{P}<0.05)$ and physical $(\mathrm{r} \geq 0.6, \mathrm{P}<0.01)$. Additionally, this study highlight that in the study area focusing on one nexus component have been encouraging in the majority of sector, i.e. food production for sustainable livelihood. In summary, the findings in this study imply that 
sustainable nexus resources can enhance livelihoods sustainability. Thus, government and nongovernmental organization need to adopt collaborative resource management measures to improve the current nexus resources insecurity. This could be attained by strong evidence based policy to ensure sustainable use of nexus resources. In addition, the results provided by this study would serve as the foundation for future study, policy formulation and implementation.

Acknowledgments: We are grateful to the Chinese Government Scholarship Council (CSC) for giving the first author a chance to pursue his Ph.D. study in China.

\title{
Funding
}

Open Access funding was enabled and organized by the National Natural Science Foundation of China (41571176) and International Cooperation and Cultivation Project of Nanjing Agricultural University (Fund No. X201915), which made this research possible.

Author Contributions: Conceptualization, Z.W. and W.W.; methodology, Z.W.; software, Z.W.; validation, Z. W, WW and H.K.; formal analysis, ZW.; investigation, ZW.; resources, ZW.; data curation, Z.W, HK; writing - original draft preparation, BK.; writing - review and editing, Z.W and BK; visualization, $\mathrm{ZW}$.; supervision, WW.; project administration, WW.; funding acquisition, WW. All authors have read and agreed to the published version of the manuscript; BK; editing and reviewing; HT; editing and reviewing

\section{Ethics approval and consent to participate}

\author{
Not applicable.
}

\section{Consent for publication}

Not applicable.

\section{Competing interests}

The authors declare that they have no competing interests.

\section{Availability of supporting data}

Not available

\section{References}

Aazami, M., Shanazi, K. (2020) Tourism wetlands and rural sustainable livelihood: The case from Iran. Journal of Outdoor Recreation and Tourism 30, 100284.

Ahmed, Z., Asghar, M.M., Malik, M.N., Nawaz, K. (2020) Moving towards a sustainable environment: the dynamic linkage between natural resources, human capital, urbanization, economic growth, and ecological footprint in China. Resources Policy 67, 101677.

Akpoti, K., Kabo-bah, A.T., Zwart, S.J. (2019) Agricultural land suitability analysis: State-of-the-art and outlooks for integration of climate change analysis. Agricultural systems 173, 172-208.

Al-Ansari, T., Korre, A., Nie, Z., Shah, N. (2015) Development of a life cycle assessment tool for the assessment of food production systems within the energy, water and food nexus. Sustainable production and consumption 2, 52-66.

Amin, S.B., Rahman, S., (2019) Water-Energy Nexus at the Heart of Sustainable Development in Bangladesh, Energy Resources in Bangladesh. Springer, pp. 117-121.

Banwet, D., Deshmukh, S. (2008) Evaluating performance of national R\&D organizations using integrated DEA-AHP technique. International journal of productivity and performance management.

Beck, M.B., Walker, R.V. (2013) On water security, sustainability, and the water-food-energy-climate nexus. Frontiers of Environmental Science \& Engineering 7, 626-639. 
Biggs, E.M., Bruce, E., Boruff, B., Duncan, J.M., Horsley, J., Pauli, N., McNeill, K., Neef, A., Van Ogtrop, F., Curnow, J. (2015) Sustainable development and the water-energy-food nexus: A perspective on livelihoods. Environmental Science \& Policy 54, 389-397.

Boas, I., Biermann, F., Kanie, N. (2016) Cross-sectoral strategies in global sustainability governance: towards a nexus approach. International Environmental Agreements: Politics, Law and Economics 16, 449-464.

Cairns, R., Krzywoszynska, A. (2016) Anatomy of a buzzword: The emergence of 'the water-energy-food nexus' in UK natural resource debates. Environmental Science \& Policy 64, 164-170.

Chandra, M.S., Naresh, R., Chaitanya, J., Charankumar, G. (2020) Impact of integrated natural resource management: challenges and experiences for sustainable livelihoods perspective: An overview.

Chartres, C.J., Noble, A. (2015) Sustainable intensification: overcoming land and water constraints on food production. Food security 7, 235-245.

Chen, B., Han, M., Peng, K., Zhou, S., Shao, L., Wu, X., Wei, W., Liu, S., Li, Z., Li, J. (2018) Global land-water nexus: agricultural land and freshwater use embodied in worldwide supply chains. Science of The Total Environment 613, 931943.

Chen, S., Tan, Y., Liu, Z. (2019) Direct and embodied energy-water-carbon nexus at an inter-regional scale. Applied Energy 251, 113401.

Costa, R.C.A., Pereira, G.T., Pissarra, T.C.T., Siqueira, D.S., Fernandes, L.F.S., Vasconcelos, V., Fernandes, L.A., Pacheco, F.A.L. (2019) Land capability of multiple-landform watersheds with environmental land use conflicts. Land use policy 81, 689-704.

de FSM Russo, R., Camanho, R. (2015) Criteria in AHP: a systematic review of literature. Procedia Computer Science 55, 1123-1132.

deLlano-Paz, F., Fernandez, P.M., Soares, I. (2019) 4.2 Paper 1: Addressing 2030 EU policy framework for energy and climate: Cost, risk and energy security issues. An application of the Modern Portfolio Theory to the optimization of the European Union power generation mix from an environmental perspective 115, 41.

do Carmo, B.B.T., Garrido, S.R., Arcese, G., Lucchetti, M.C., (2020) Weighting and scoring in Social Life Cycle Assessment, Perspectives on Social LCA. Springer, pp. 45-52.

Donkor, E., Owusu, V. (2019) Mineral Fertiliser Adoption and Land Productivity: Implications for Securing Stable Rice Production in Northern Ghana. Land 8, 59.

Elfimova, Y., Ivolga, A., Ryazantsev, I., (2020) Food Security Through Rational Land Management: Innovative Aspects and Practices, Handbook of Research on Globalized Agricultural Trade and New Challenges for Food Security. IGI Global, pp. 129-146.

Elias, E., Seifu, W., Tesfaye, B., Girmay, W. (2019) Impact of land use/cover changes on lake ecosystem of Ethiopia central rift valley. Cogent Food \& Agriculture 5, 1595876.

Estoque, R.C., Togawa, T., Ooba, M., Gomi, K., Nakamura, S., Hijioka, Y., Kameyama, Y. (2019) A review of quality of life (QOL) assessments and indicators: Towards a "QOL-Climate" assessment framework. Ambio 48, 619-638.

Funke, N., Nortje, K., Meissner, R., Steyn, M., Ntombela, C., (2019) An Analysis of International and South African Discourses and Perspectives on Water Security, Understanding Water Security at Local Government Level in South Africa. Springer, pp. 45-71.

Gashu, K., Muchie, Y. (2018) Rethink the interlink between land degradation and livelihood of rural communities in Chilga district, Northwest Ethiopia. Journal of Ecology and Environment 42, 1-11.

Granit, J., Jägerskog, A., Lindström, A., Björklund, G., Bullock, A., Löfgren, R., de Gooijer, G., Pettigrew, S. (2012) Regional options for addressing the water, energy and food nexus in Central Asia and the Aral Sea Basin. International Journal of Water Resources Development 28, 419-432.

Gulati, M., Jacobs, I., Jooste, A., Naidoo, D., Fakir, S. (2013) The water-energy-food security nexus: Challenges and opportunities for food security in South Africa. Aquatic Procedia 1, 150-164.

Harmancioglu, N.B., Cetinkaya, C.P., Barbaros, F., (2020) Sustainability Issues in Water Management in the Context of Water Security, Water Resources of Turkey. Springer, pp. 517-533.

Hassen, G., Bantider, A., Legesse, A., Maimbo, M. (2021) Assessment of Design and Constraints of Physical Soil and Water Conservation Structures in respect to the standard in the case of Gidabo sub-basin, Ethiopia. Cogent Food \& Agriculture 7, 1855818.

Helmy, I., (2020) Livelihood Diversification Strategies: Resisting Vulnerability in Egypt. GLO Discussion Paper. Hinshelwood, E. (2003) Making friends with the sustainable livelihoods framework. Community Development Journal 38, 243-254.

Hosmer, D.W., Lemeshow, S. (2000) Applied Logistic Regression. John Wiley \& Sons. New York. Hurni, H., Abate, S., Bantider, A., Debele, B., Ludi, E., Portner, B., Yitaferu, B., Zeleke, G. (2010) Land degradation and sustainable land management in the highlands of Ethiopia. 
Jendoubi, D., Hossain, M.S., Giger, M., Tomićević-Dubljević, J., Ouessar, M., Liniger, H., Speranza, C.I. (2020) Local livelihoods and land users' perceptions of land degradation in northwest Tunisia. Environmental development 33, 100507.

Karlberg, L., Hoff, H., Amsalu, T., Andersson, K., Binnington, T., Flores-López, F., de Bruin, A., Gebrehiwot, S.G., Gedif, B., Johnson, O. (2015) Tackling complexity: understanding the food-energy-environment nexus in Ethiopia's Lake tana sub-basin. Water Alternatives 8.

Kebebe, E., Shibru, F. (2017) Impact of alternative livelihood interventions on household welfare: Evidence from rural Ethiopia. Forest Policy and Economics 75, 67-72.

Khan, S., Khan, M., Hanjra, M., Mu, J. (2009) Pathways to reduce the environmental footprints of water and energy inputs in food production. Food policy 34, 141-149.

Kumar, H., Pandey, B., Anand, S. (2019) Analyzing the Impacts of forest Ecosystem Services on Livelihood Security and Sustainability: A Case Study of Jim Corbett National Park in Uttarakhand. International Journal of Geoheritage and Parks 7, 45-55.

Kurian, M. (2017) The water-energy-food nexus: trade-offs, thresholds and transdisciplinary approaches to sustainable development. Environmental Science \& Policy 68, 97-106.

Kurian, M., Scott, C., Reddy, V.R., Alabaster, G., Nardocci, A.C., Portney, K., Boer, R., Hannibal, B. (2019) One Swallow Does Not Make a Summer: Siloes, Trade-Offs and Synergies in the Water-Energy-Food Nexus. Frontiers in Environmental Science 7, 32.

Lan, X., Zhang, Q., Xue, H., Liang, H., Wang, B., Wang, W. (2021) Linking sustainable livelihoods with sustainable grassland use and conservation: A case study from rural households in a semi-arid grassland area, China. Land use policy 101, 105186

Laspidou, C.S., Mellios, N., Kofinas, D. (2019) Towards Ranking the Water-Energy-Food-Land Use-Climate Nexus Interlinkages for Building a Nexus Conceptual Model with a Heuristic Algorithm. Water 11, 306.

Laurett, R., Paço, A., Mainardes, E.W. (2021) Sustainable Development in Agriculture and its Antecedents, Barriers and Consequences-An Exploratory Study. Sustainable production and consumption 27, 298-311.

Leck, H., Conway, D., Bradshaw, M., Rees, J. (2015) Tracing the water-energy-food nexus: Description, theory and practice. Geography Compass 9, 445-460.

Lee, S.-H., Mohtar, R.H., Yoo, S.-H. (2019) Assessment of food trade impacts on water, food, and land security in the MENA region. Hydrology and Earth System Sciences 23, 557-572.

Leese, M., Meisch, S. (2015) Securitising sustainability? Questioning the'water, energy and food-security nexus'. Water Alternatives 8 .

Li, Y., Wang, S., Chen, B. (2019) Driving force analysis of the consumption of water and energy in China based on LMDI method. Energy Procedia 158, 4318-4322.

Liu, J., Yang, H., Cudennec, C., Gain, A.K., Hoff, H., Lawford, R., Qi, J., Strasser, L.d., Yillia, P., Zheng, C. (2017) Challenges in operationalizing the water-energy-food nexus. Hydrological Sciences Journal 62, 1714-1720.

Mabhaudhi, T., Nhamo, L., Mpandeli, S., Nhemachena, C., Senzanje, A., Sobratee, N., Chivenge, P.P., Slotow, R., Naidoo, D., Liphadzi, S. (2019) The Water-Energy-Food Nexus as a Tool to Transform Rural Livelihoods and Well-Being in Southern Africa. International journal of environmental research and public health 16, 2970.

Marker, P., McNamara, K., Wallace, L. (2002) The significance of information and communication technologies for reducing poverty. London, UK: DFID.

Mazziotta, M., Pareto, A. (2019) Use and misuse of PCA for measuring well-being. Social Indicators Research 142, 451476.

Mazzone, A. (2019) Decentralised energy systems and sustainable livelihoods, what are the links? Evidence from two isolated villages of the Brazilian Amazon. Energy and Buildings 186, 138-146.

Meixner, O., Haas, R., Pöchtrager, S., (2016) AHP group decision making and clustering, International Symposium on the Analytic Hierarchy Process (ISAHP). http://www. isahp. org/uploads/paper_mo_hr_isahp2016rev_001. pdf. Accessed September, p. 2016.

Mekuria, W., Yami, M., Haile, M., Gebrehiwot, K., Birhane, E. (2019) Impact of exclosures on wood biomass production and fuelwood supply in northern Ethiopia. Journal of Forestry Research 30, 629-637.

Mendoza, L.C., Cruz, G.A., Ciencia, A.N., Penalba, M.A. (2020) Local Policy and Water Access in Baguio City, Philippines. International Journal of Social Ecology and Sustainable Development (IJSESD) 11, 1-13.

Meshesha, D.T., Tsunekawa, A., Tsubo, M. (2012) Continuing land degradation: cause-effect in Ethiopia's Central Rift Valley. Land degradation \& development 23, 130-143.

Mohtar, R.H., Daher, B. (2016) Water-energy-food nexus framework for facilitating multi-stakeholder dialogue. Water International 41, 655-661.

Mohtar, R.H., Lawford, R. (2016) Present and future of the water-energy-food nexus and the role of the community of practice. Journal of Environmental Studies and Sciences 6, 192-199. 
Moldan, B., Janoušková, S., Hák, T. (2012) How to understand and measure environmental sustainability: Indicators and targets. Ecological indicators 17, 4-13.

Nguyen, D.T. (2019) Dynamics of household-level energy access in Vietnam during 2002-2014.

Nhamo, L., Mabhaudhi, T., Mpandeli, S., Dickens, C., Nhemachena, C., Senzanje, A., Naidoo, D., Liphadzi, S., Modi, A.T. (2020) An integrative analytical model for the water-energy-food nexus: South Africa case study. Environmental Science \& Policy 109, 15-24.

Nie, Y., Avraamidou, S., Xiao, X., Pistikopoulos, E.N., Li, J., Zeng, Y., Song, F., Yu, J., Zhu, M. (2019) A Food-EnergyWater Nexus approach for land use optimization. Science of The Total Environment 659, 7-19.

Paul, S., Das, T.K., Pharung, R., Ray, S., Mridha, N., Kalita, N., Ralte, V., Borthakur, S., Burman, R.R., Tripathi, A.K. (2020) Development of an indicator based composite measure to assess livelihood sustainability of shifting cultivation dependent ethnic minorities in the disadvantageous Northeastern region of India. Ecological Indicators 110, 105934. Pimentel, D., Whitecraft, M., Scott, Z.R., Zhao, L., Satkiewicz, P., Scott, T.J., Phillips, J., Szimak, D., Singh, G., Gonzalez, D.O. (2010) Will limited land, water, and energy control human population numbers in the future? Human Ecology 38, 599-611.

Plummer, J., Slaymaker, T. (2007) Rethinking governance in water services. ODI.

Rasul, G., Sharma, B. (2016) The nexus approach to water-energy-food security: an option for adaptation to climate change. Climate Policy 16, 682-702.

Ray, B., Shaw, R., (2019) Developing Water Security Index for Urban Areas, Urban Drought. Springer, pp. 53-68. Revell, P., Henderson, C. (2019) Operationalising a framework for understanding community resilience in Europe. Regional Environmental Change 19, 967-979.

Ringler, C., Bhaduri, A., Lawford, R. (2013) The nexus across water, energy, land and food (WELF): potential for improved resource use efficiency? Current Opinion in Environmental Sustainability 5, 617-624.

Robinne, F.-N., Parisien, M.-A., Flannigan, M., Miller, C., Bladon, K.D., (2017) A global assessment of wildfire risks to human and environmental water security, EGU General Assembly Conference Abstracts, p. 9080.

Rydin, Y., Holman, N., Wolff, E. (2003) Local sustainability indicators. Local Environment 8, 581-589.

Saaty, T.L., (2016) The analytic hierarchy and analytic network processes for the measurement of intangible criteria and for decision-making, Multiple criteria decision analysis. Springer, pp. 363-419.

Salim, Y. (2019) LIVELIHOOD SUSTAINABILITY AMONG ROHINGYA REFUGEES: A CASE STUDY IN TAMAN SENANGIN, SEBERANG PERAI, PENANG. Asia Proceedings of Social Sciences 4, 46-48.

Sarker, M.N.I., Wu, M., Alam, G.M., Shouse, R.C. (2020) Livelihood diversification in rural Bangladesh: Patterns and determinants in disaster prone riverine islands. Land use policy 96, 104720.

Scoones, I. (1998) Sustainable rural livelihoods: a framework for analysis.

Shahzad, M.W., Burhan, M., Ang, L., Ng, K.C. (2017) Energy-water-environment nexus underpinning future desalination sustainability. Desalination 413, 52-64.

Siciliano, G., Rulli, M.C., D'odorico, P. (2017) European large-scale farmland investments and the land-water-energyfood nexus. Advances in Water Resources 110, 579-590.

Smajgl, A., Ward, J., Pluschke, L. (2016) The water-food-energy Nexus-Realising a new paradigm. Journal of hydrology 533, 533-540.

Spera, S.A., Galford, G.L., Coe, M.T., Macedo, M.N., Mustard, J.F. (2016) Land-use change affects water recycling in Brazil's last agricultural frontier. Global change biology 22, 3405-3413.

Spiegelberg, M., Baltazar, D.E., Sarigumba, M.P.E., Orencio, P.M., Hoshino, S., Hashimoto, S., Taniguchi, M., Endo, A. (2017) Unfolding livelihood aspects of the water-energy-food nexus in the dampalit watershed, Philippines. Journal of Hydrology: Regional Studies 11, 53-68.

Steenkamp, J., Cilliers, E.J., Cilliers, S.S., Lategan, L. (2021) Food for Thought: Addressing Urban Food Security Risks through Urban Agriculture. Sustainability 13, 1267.

Swatuk, L.A., Cash, C., (2018) Perspectives on the Nexus: Water, Energy and Food Security in an Era of Climate Change, Water, Energy, Food and People Across the Global South. Springer, pp. 1-13.

Terrapon-Pfaff, J., Ortiz, W., Dienst, C., Gröne, M.-C. (2018) Energising the WEF nexus to enhance sustainable development at local level. Journal of environmental management 223, 409-416.

Tian, H., Lu, C., Pan, S., Yang, J., Miao, R., Ren, W., Yu, Q., Fu, B., Jin, F.-F., Lu, Y. (2018) Optimizing resource use efficiencies in the food-energy-water nexus for sustainable agriculture: from conceptual model to decision support system. Current Opinion in Environmental Sustainability 33, 104-113.

Varis, O., Keskinen, M., Kummu, M. (2017) Four dimensions of water security with a case of the indirect role of water in global food security. Water Security 1, 36-45.

Vivoda, V., (2017) Energy security issues in Asia, Routledge Handbook of Energy in Asia. Routledge, pp. 272-283.

Wicaksono, A., Jeong, G., Kang, D. (2017) Water, energy, and food nexus: review of global implementation and simulation model development. Water Policy 19, 440-462. 
Wicaksono, A., Kang, D. (2019) Nationwide simulation of water, energy, and food nexus: Case study in South Korea and Indonesia. Journal of Hydro-environment Research 22, 70-87. Wichelns, D. (2017) The water-energy-food nexus: Is the increasing attention warranted, from either a research or policy perspective? Environmental Science \& Policy 69, 113-123. Wolde, Z., Wei, W., Kunpeng, W., Ketema, H. (2020) Local community perceptions toward livelihood and waterenergy-food nexus: A perspective on food security. Food and Energy Security 9, e207. WoldeYohannes, A., Cotter, M., Kelboro, G., Dessalegn, W. (2018) Land use and land cover changes and their effects on the landscape of Abaya-Chamo Basin, Southern Ethiopia. Land 7, 2. Quantifying the Sustainability of Water Availability for the Water-Food-Energy-Ecosystem Nexus in the Niger River Basin. Earth's future 6, 1292-1310. Yared, B., (2019) Estimation of Catchment Sediment Yield using SWAT Model (Case Study Gidabo Dam, Rift Valley Basin, Ethiopia). Addis Ababa University.

807 